\title{
FISHERY EXPLOITATION AND STOCK ASSESSMENT OF THE ENDANGERED NASSAU GROUPER, EPINEPHELUS STRIATUS (ACTINOPTERYGII: PERCIFORMES: SERRANIDAE), IN THE TURKS AND CAICOS ISLANDS
}

\author{
Anh-Thu E. VO ${ }^{1,2^{*}}$, Matthew C. ASHLEY ${ }^{1,3}$, Angela DIKOU ${ }^{1,4}$, and Steven P. NEWMAN ${ }^{1,5}$ \\ ${ }^{1}$ Center for Marine Resource Studies, The School for Field Studies, 1 West Street, South Caicos, \\ Turks and Caicos Islands, British West Indies \\ ${ }^{2}$ Museum of Vertebrate Zoology and Department of Integrative Biology, \\ University of California, Berkeley, California, USA \\ ${ }^{3}$ Plymouth Marine Laboratory, Plymouth, Devon, UK and School of Marine Science and Engineering, \\ University of Plymouth, Plymouth, Devon, UK \\ ${ }^{4}$ College of Science and Mathematics, University of the Virgin Islands, St. Thomas, USVI \\ ${ }^{5}$ School of Marine Science and Technology, Newcastle University, Newcastle Upon Tyne, UK
}

\begin{abstract}
Vo A.-T.E., Ashley M.C., Dikou A., Newman S.P. 2014. Fishery exploitation and stock assessment of the endangered Nassau grouper, Epinephelus striatus (Actinopterygii: Perciformes: Serranidae), in the Turks and Caicos Islands. Acta Ichthyol. Piscat. 44 (2): 117-122.
\end{abstract}

Background. The Nassau grouper, Epinephelus striatus (Bloch, 1792), is an endangered species that has been historically overexploited in numerous fisheries throughout its range in the Caribbean and tropical West Atlantic. Data relating fishery exploitation levels to stock abundance of the species are deficient, and protective regulations for the Nassau grouper are yet to be implemented in the Turks and Caicos Islands (TCI). The goal of this study was to conduct a stock assessment and evaluate the exploitation status of the Nassau grouper in the TCI. Materials and methods. Calibrated length cohort analysis was applied to published fisheries data on Nassau grouper landings in the TCI. The total lengths of Nassau groupers among the catches of spearfishers, lobster trappers, and deep sea fishers on the island of South Caicos during 2006 and 2008 were used with estimates of growth, natural mortality, and total annual landings to derive exploitation benchmarks.

Results. The TCI stock experienced low to moderate fishing mortality $(0.28,0.18)$ and exploitation rates $(0.49$, $0.38)$ during the period of the study $(2006,2008)$. However, $21.2 \%-64.4 \%$ of all landings were reproductively immature. Spearfishing appeared to contribute most to fishing mortality relative to the use of lobster traps or hydraulic reels along bank drop-offs.

Conclusion. In comparison with available fisheries data for the wider Caribbean, the results reveal the TCI as one of the remaining sites, in addition to the Bahamas, with a substantial Nassau grouper stock. In light of increasing development and tourism in the TCI, continued monitoring is essential to maintain sustainable harvesting practices.

Keywords: small-scale fisheries, calibrated length-cohort analysis, mass-at-size estimates, exploitation, maximum sustainable yield, fisheries management regulations

\section{INTRODUCTION}

Declines in wild fish stocks to supply human consumption have been observed repeatedly throughout history (Pauly 2008) and have been pervasive in the Caribbean (Graham et al. 2008, Hardt 2009, Paddack et al. 2009, Box and Canty 2010). Although once considered the most commonly landed grouper in the Caribbean and western Atlantic (Sadovy and Eklund 1999), the Nassau grouper,
Epinephelus striatus (Bloch, 1792), is becoming particularly scarce. Of 60 to 80 historical Nassau grouper spawning aggregations throughout its distribution, a third are estimated to have disappeared due to overfishing, and aggregation sizes have declined from tens of thousands to as few as 100 individuals per aggregation (Sadovy and Eklund 1999). The global population size has experienced an estimated 60-percentage-point decline over 30 years beginning in the

\footnotetext{
* Correspondence: Dr. Anh-Thu E. Vo, 3101 Valley Life Sciences Building, University of California, Berkeley, CA 94720-3140, USA e-mail: (ATEV)
} vo@berkeley.edu, (MCA) matthew.ashley@plymouth.ac.uk,(AD) angeladikou@hotmail.com, (SPN) steve.newman@ncl.ac.uk. 
early 1970s (Cornish and Eklund 2003), and it is predicted with high likelihood to continue declining for the foreseeable future (Cornish and Eklund 2003, Sadovy de Mitcheson et al. 2013). Thus, the Nassau grouper is classified as endangered by the International Union for Conservation of Nature (Cornish and Eklund 2003).

The Turks and Caicos Islands (TCI), located in the tropical West Atlantic, possess robust fisheries that have long harvested Nassau grouper (Rudd 2003, Vo et al. 2008, Landsman et al. 2009). Analyses of 16 Nassau grouper populations throughout the Caribbean basin found no evidence for a genetically distinct enclave in the TCI (Anonymous et al. 2012, Jackson et al. 2014). Therefore, high stock connectivity throughout the eastern Caribbean warrants stock assessments in multiple sites to understand status implications and inform management actions for the meta-population. Prior studies in the TCI reported descriptive statistics of length distribution data from fisheries landings as well as interview data on the capture and valuation of Nassau grouper (Vo et al. 2008, Landsman et al. 2009). Although these studies comprise informative integrations of ecological and socioeconomic data, they represent missed opportunities to utilize the data to directly address the status of the stock in the context of exploitation rates and stock abundance. Therefore, this study applies calibrated length cohort analysis (Pauly 1984, Ehrhardt and Deleveaux 2007) on the fisheries data from Vo et al. (2008) and Landsman et al. (2009) in order to quantify fishing pressure and derive preliminary estimates of stock sustainability in the TCI. Despite the endangered status of the Nassau grouper, no protective regulations are currently in place in the fisheries of the TCI. The results of this study enable evaluation of the stock relative to other sites in the region to provide insight on the exploitation status as well as management opportunities for this endangered species.

\section{MATERIALS AND METHODS}

Study area. The Turks and Caicos Islands (TCI), located at the southern end of the Bahamian Archipelago, are comprised of the Caicos, Turks, and Mouchoir Banks as well as several islands and small cays (Fig. 1). The Caicos Bank is a shallow, oolitic limestone platform encompassing an area of $6140 \mathrm{~km}^{2}$; Turks Bank, an area of $324 \mathrm{~km}^{2}$; and Mouchoir Bank, an area of $1109 \mathrm{~km}^{2}$ (Olsen 1986). Water depths range from 1-5 $\mathrm{m}$ throughout the banks, 20-30 $\mathrm{m}$ at the top of the drop-offs, and over $1800 \mathrm{~m}$ beyond the drop-offs. The TCI government is centered on Grand Turk; tourism, on Providenciales; and fishing, on South Caicos. Biological surveys of Nassau Grouper catches were conducted on South Caicos.

Tourism constitutes a rapidly expanding industry (annual growth rates between one and 41 percentage points from 2003 through 2007) and contributed to roughly one third of the Turks and Caicos Islands GDP in 2009 (Anonymous 2009a). Small-scale fisheries also figure prominently in the TCI economy, wherein queen conch, Strombus gigas, and spiny lobster, Panulirus argus, predominantly drive exports (US\$24.77 million in 2008; Anonymous 2014). Although not exported, scale fish

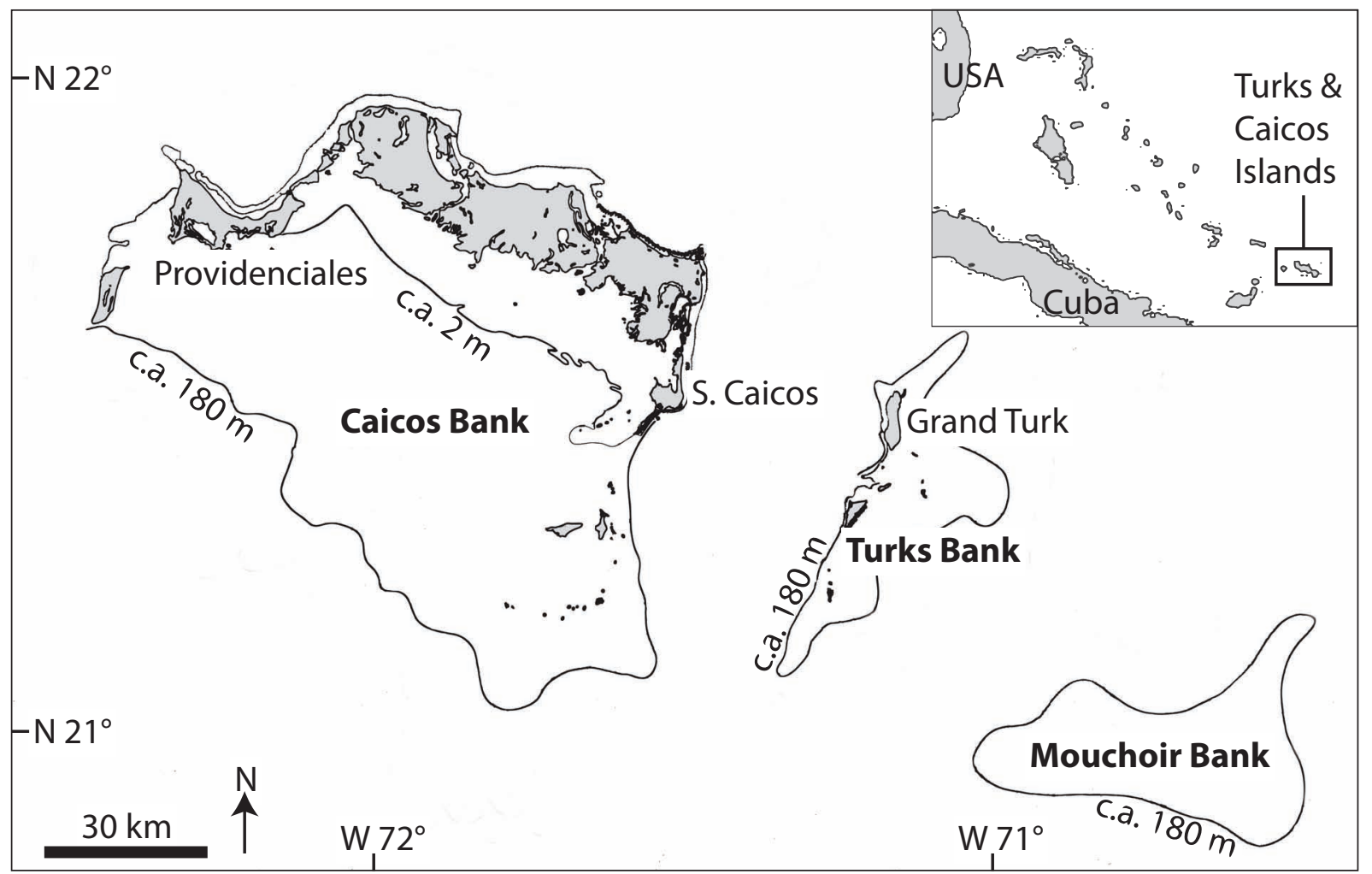

Fig. 1. Map of the Turks and Caicos Islands (TCI) showing isobaths of 2 and $180 \mathrm{~m}$; Inset illustrates the location of the TCI in the tropical West Atlantic 
landings grew by a factor of 2.5 from 1995 to 2002 (Anonymous 2009b). Increases in fishing pressure are anticipated indirectly through increases in tourism, and plans exist for the formation of a Fisheries Advisory Committee to oversee the management and development of the fisheries (Anonymous 2009c).

Fisheries data. Multiple catches of 12 commercial divers ( $\sim 9 \%$ of licensed South Caicos fishermen at the time of sampling), four lobster trap boats (two large-scale, two small-scale; $100 \%$ of known South Caicos lobster boats), and two deep sea fishing boats (100\% of known South Caicos deep sea boats) were sampled during 22 November-6 December 2006 (Vo et al. 2008), 14-24 April 2008, and 6-29 August 2008 (Landsman et al. 2009). In each sampled catch, Nassau grouper total lengths (TL) and mass were recorded for all individuals landed via commercial divers' spearfishing $(n=82)$, lobster trap bycatch $(n=57)$, and deep sea bank drop-off or wall-fishing with hydraulic reels ( $n=35$; hereafter, "wall-fishing"). Total length was measured from the tip of the snout to the longer lobe of the caudal fin compressed along the midline.

Data analysis. To perform the calibrated length cohort analysis, estimates of von Bertalanffy growth coefficient, natural mortality, and total annual landings for Nassau grouper, Epinephelus striatus, in the TCI were needed. A growth coefficient of 0.111 year $^{-1}$ was used, following Ehrhardt and Deleveaux's (2007) comparative analysis of all grouper species in the family Epinephelinae including Nassau grouper. Natural mortality was calculated from Froese and Binohlan's (2000) empirical relations, wherein asymptotic length was derived from the maximum length $(122 \mathrm{~cm} \mathrm{TL})$ recorded in this study, and natural mortality was subsequently calculated from the asymptotic length, growth coefficient, and TCI's mean annual water temperature $\left(27^{\circ} \mathrm{C}\right.$; Sheppard and Rioja-Nieto 2005). The derived natural mortality rate of 0.29 for the TCI was consistent with reported estimates of $0.17-0.30$ for Jamaica (Thompson and Munro 1978) and 0.18 for Cuba (Ehrhardt and Deleveaux 2007). Of note, the site-specific estimates of asymptotic length and natural mortality were derived using data from this study to provide the most relevant values for the calibrated length cohort analysis, rather than applying reported estimates from other sites, because life history traits are dependent on local environments. Total annual landings were extrapolated from the length frequency data for each sample year, by taking the product of the mean daily catch of the sampled duration within the year and the number of days in a year, excluding one month for spawning. The designated one month comprised a conservative approach to account for the aggregate unavailability of Nassau grouper to this open fishery, when the species makes multiple, brief trips to spawning aggregation sites from late November through early February and during which decreased commercial catch has been documented (Sadovy and Eklund 1999).

Calibrated length cohort analysis of Epinephelus striatus was performed on the extrapolated annual landings data (Pauly 1984, Ehrhardt and Deleveaux 2007). This stock assessment algorithm uses a length-converted catch equation (Pauly 1984) to estimate total mortality rate $(Z)$, which is then used to estimate fishing mortality rate $(F)$ and exploitation rate $(F / Z)$. Population sizes for various size classes were subsequently calculated to determine preliminary stock abundance estimates in the absence of catch per unit effort data (Cheung et al. 2013). Stock numerical abundance was converted to biomass abundance based on mass-at-size estimates, which were derived from regression analysis of empirical total mass and total length data from Vo et al. (2008) and Landsman et al. (2009). Stock numerical and biomass $(B)$ abundances were standardized by total reef area $\left(\mathrm{TCI}=1200 \mathrm{~km}^{2}\right.$ and Bahamas $=1987 \mathrm{~km}^{2}$; Woodley et al. 2000). Fishing mortality and population biomass at maximum sustainable yield ( $F_{\mathrm{msy}}$ and $\left.B_{\mathrm{msy}}\right)$ were used to derive further exploitation benchmarks $\left(F / F_{\mathrm{msy}}\right.$ and $B / B_{\mathrm{msy}}$; Ault et al. 2005). Values of $F / Z, F / F_{\mathrm{msy}}$, and $B / B_{\mathrm{msy}}$ indicative of overexploitation correspond to $>0.5,<1$, and $>1$, respectively. For the determination of immature landings, a liberal $(40 \mathrm{~cm})$ and a conservative $(63.8 \mathrm{~cm})$ total length threshold were both applied to represent the range of lengths at sexual maturation $\left(L_{\mathrm{m}}\right)$ observed in previous studies (Sadovy and Eklund 1999, Ehrhardt and Deleveaux 2007) and the presently reported study, respectively.

\section{RESULTS AND DISCUSSION}

Based on the available TCI fisheries data, preliminary stock numerical abundance of the Nassau grouper, Epinephelus striatus, was estimated to be 23 and 164 per square kilometer of reef area in 2006 and 2008, respectively (Table 1). Stock abundance in biomass was calculated from the product of mass-at-size estimates using empirical data from $2006\left(\mathrm{TM}=0.00000459 \times \mathrm{TL}^{3.3026}\right.$, where $\mathrm{TM}$ is total mass and TL is total length, range $=33.4-73.1 \mathrm{~cm}, n=$ 30) and corresponding numerical abundance-at-size estimated from the calibrated length cohort analysis. Total biomass of the Nassau grouper stock in the TCI was approxi-

Table 1

Stock assessment of Nassau grouper, Epinephelus striatus; results based on extrapolated South Caicos fisheries data from 2006 and 2008 for the Turks and Caicos Islands

\begin{tabular}{lcc}
\hline Variable & 2006 & 2008 \\
\hline Recruitment [No.] & 30509 & 5629 \\
Stock abundance [No.] & 196334 & 28104 \\
Catch [No.] & 3465 & 1635 \\
Stock abundance [t] & 694 & 79 \\
Fishing mortality $(F)$ & 0.28 & 0.18 \\
Exploitation rate $(F / Z)$ & 0.49 & 0.38 \\
$F / F_{\text {msy }}$ & 0.97 & 0.62 \\
$B / B_{\text {msy }}$ & 1.01 & 1.67 \\
\hline
\end{tabular}

$F_{\text {msy }}=$ fishing mortality at maximum sustainable yield, $B_{\text {msy }}=$ population biomass at maximum sustainable yield. 
mated to be 0.07 and $0.58 \mathrm{t} \cdot \mathrm{km}^{-2}$ of reef area in 2006 and 2008, respectively (Table 1). Both numerical and biomass abundance estimates for the TCI were lower than that of the Bahamas (17 000-22 000 individuals $\cdot \mathrm{km}^{-2}$ reef and $58-67 \mathrm{t} \cdot \mathrm{km}^{-2}$ reef; Ehrhardt and Deleveaux 2007). However, overexploitation has led to sharp declines in Nassau grouper landings and rendered it commercially insignificant throughout the rest of its former range (Sadovy and Eklund 1999, Cheung et al. 2013). Thus, comparable contemporary stock data are deficient for other Nassau grouper fisheries in the greater Caribbean, and the TCI appear to be among the few remaining known areas in the wider Caribbean with a substantial Nassau grouper population.

The estimates of 0.28 and 0.18 for fishing mortality of the Nassau grouper, in 2006 and 2008, respectively, were intermediate relative to historical estimates from the 1990s for other fisheries in the wider Caribbean: 0.06-0.11 in the Bahamas, 0.21 for the Cayman Islands, 0.25 in Florida, 0.30 for Puerto Rico, and 0.35 in Belize (Ehrhardt and Deleveaux 2007). Such high fishing mortality in Florida, Puerto Rico, and Belize has corresponded with a depletion of older individuals in fisheries landings and a marked decline in spawning aggregations (Ehrhardt and Deleveaux 2007). Nassau grouper exploitation rate was calculated to be 0.49 in 2006 and 0.38 in 2008 for the TCI, which fall just below 0.50 where the maximum sustainable yield should theoretically be set (Ehrhardt and Deleveaux 2007). Additional exploitation benchmarks $\left(F / F_{\text {msy }}\right.$ and $\left.B / B_{\text {msy }}\right)$ indicated that the stock was harvested right at maximum sustainable yield in $2006\left(F / F_{\text {msy }}=0.49\right.$ and $\left.B / B_{\mathrm{msy}}=1.01\right)$ and less exploited in $2008\left(F / F_{\mathrm{msy}}=0.62\right.$ and $\left.B / B_{\mathrm{msy}}=1.67\right)$. To explore the extent to which exploitation varied by fishing method, length calibrated cohort analysis was also performed on subsets of the length distribution data according to gear used (spears, lobster traps, and hydraulic reels). Although estimates derived from these subsample analyses lacked power, they suggested high variation in exploitation among fishing methods. Considerable fishing mortality (0.23) and exploitation (0.44) was only identified among spearfished groupers. For trapped and reeled individuals, total mortality did not exceed natural mortality.

Altogether, the exploitation estimates reveal moderate Nassau grouper fishing pressure. However, they also demonstrate the potential for harvest to approach maximum sustainable yield and become a cause for concern without regulatory oversight. This is especially true given that the length distributions of landed Nassau groupers among various surveyed fishing methods (Vo et al. 2008, Landsman et al. 2009) have revealed a substantial percentage of reproductively immature individuals $(64.4 \%$ using site-specific, conservative $L_{\mathrm{m}}$ of $62.8 \mathrm{~cm} \mathrm{TL} ; 21.3 \%$ using liberal $L_{\mathrm{m}}$ of $40 \mathrm{~cm} \mathrm{TL}$ ). Furthermore, of all fishing methods previously surveyed, spearfishing yielded the highest proportion of immature individuals among the landings $\left(81.7 \%\right.$ with $L_{\mathrm{m}}$ of $62.8 \mathrm{~cm} \quad \mathrm{TL}, 34.1 \%$ with $L_{\mathrm{m}}$ of $\left.40 \mathrm{~cm} \mathrm{TL}\right)$. The variation in immature landings by fishing method was likely associated with targeted fishing depths and preferred fish size (as summarized in Vo et al. 2008): spearfishers exploited shallow waters ( $\leq 18 \mathrm{~m}$ depths) and targeted smaller groupers; lobster trappers exploited intermediate water depths $(20-30 \mathrm{~m})$ and discarded smaller individuals $(<0.90 \mathrm{~kg})$ whereas wall-fishers exploited deep waters (90 to $400 \mathrm{~m}$ ) and targeted the largest individuals.

No documentation of total annual catch was available for the Nassau grouper in the TCI, and data collection for research on small scale fisheries can be challenging given the variety of gear types, targeted species, landing sites, and large areas of operation involved. Furthermore, the TCI implement annual no-take seasons for spiny lobster from 1 April through 31 July, thereby lobster trap bycatch of Nassau grouper was precluded during this period. These complicating factors limited sampling opportunities and resulted in stratified sampling in Vo et al. (2008) and Landsman et al. (2009). However, calibrated length cohort analysis is robust for data-deficient and highly stratified fisheries datasets (Ehrhardt and Deleveaux 2007). All analyses assume constant natural mortality, fishing mortality, recruitment, and thereby length frequency distributions over time. Intra- and inter-annual variation in factors such as fishing activity, ocean temperatures, and predation pressure can affect the representativeness and accuracy of estimates from the calibrated length cohort analysis. Nevertheless, the results herein are presented to facilitate a better understanding of the TCI fisheries and stock.

\section{CONCLUSION AND IMPLICATIONS}

The TCI have long been regarded as an important source and sink for marine larvae within the greater Caribbean (Roberts 1997, Jackson et al. 2014). Given the history of overexploitation of the Nassau grouper, Epinephelus striatus, throughout the Caribbean (Sadovy and Eklund 1999), abundance estimates for the TCI implicated the Nassau grouper stock to be significant as the only sizeable, documented, contemporary population in addition to that of the Bahamas (Ehrhardt and Deleveaux 2007). The TCI stock was utilized at moderate exploitation levels and within the range of sustainability during the short time period of this study. These results suggest a healthy TCI stock. However, the rapidly growing tourism industry is likely to raise demand for Nassau grouper as a favored food fish (Rudd 2003). Among the reef fishes, Nassau grouper has been historically and is still locally preferred over other species for their size and quality of flesh in the TCI (Rudd 2003, Vo et al. 2008, Landsman et al. 2009). Exploitation rates near maximum sustainable yield were observed during one sample year of this study, and a notable proportion of landed individuals across both years were reproductively immature, whereby spearfishing yielded the highest proportion of immature groupers among landings (Vo et al. 2008). Sadovy de Mitcheson et al. (2013) reported that the risk of extinction for exploited species facing uncontrolled fishing pressure by long established fisheries is generally underestimated by IUCN criteria. The implementation of size restrictions, close monitoring of spearfished landings, and a closed fishing season with protection of spawning aggregations for 
Nassau grouper in the TCI fisheries may be necessary to help maintain sustainability of the Nassau grouper stock. Such regulations already exist in the TCI for spiny lobster and thus may be tractable with the fisher community. In recognition of the vulnerability of Nassau grouper to fishery exploitation, the Government of the Bahamas has implemented strategic precautionary measures, including a minimum size restriction (Sadovy and Eklund 1999) and a prohibition on the harvest of spawning Nassau grouper (Ehrhardt and Deleveaux 2007), which appear to be effective in maintaining an abundant stock in the Bahamas. The TCI are likewise in the rare and privileged position to be proactive in maintaining their current Nassau grouper stock, and in light of global declines in this endangered species, conservation opportunities should be considered a priority for appropriate management.

\section{ACKNOWLEDGEMENTS}

The authors gratefully acknowledge John Claydon, Elise Magarian, South Caicos fishermen, Turks and Caicos Islands Department of Environment and Maritime Affairs, and key financial and field logistical support provided by the Center for Marine Resource Studies of the School for Field Studies. The authors are also thankful to anonymous reviewers for thoughtful comments on earlier versions of the manuscript.

\section{REFERENCES}

Anonymous 2009a. Tourism. DEPS Website. Department of Economic Planning and Statistics, Turks and Caicos Islands. Accessed March 2014 at: http:/www.depstc.org/stat/economic/ tourism.html

Anonymous 2009b. Fishing Activity. DEPS Website. Department of Economic Planning and Statistics, Turks and Caicos Islands. Accessed March 2014 at: http://www.depstc.org/stat/economic/fishing.html

Anonymous 2009c. Chapter. 10.08. Fisheries Protection Ordinance and Subsidiary Legislation. In: Laws of Turks \& Caicos Islands. The Regional Law Revision Centre Inc., Turks and Caicos Islands. Accessed March 2014 at: http://www.gov.tc/environment/sites/default/files/10.08\%20 Fisheries\%20Protection\%20Ordinance_3.pdf

Anonymous, Abelló P., Ai W., Altmann C., Bernardi G., Bonato O., Burchhardt K.M., Chen X., Chen Z., Č́žžková D., Clouet C., Cubeta M.A., Garcia-Merchan V.H., Gauthier N., Gibson S., Halačka K., Hamdi F., Hankeln T., Hochkirch A., Hrbek T., Jackson A.M., Lin C., Lin S.-M., Macpherson E., Macrander J., Marešová E., Mendel J., Nowak M., Orti G., Palero F., Papoušek I., Pascual M., Schmitt T., Semmens B.X., Streito J.-C., Tian E.-W., Tseng S.-P., Veith M., Vetešník L., Wang H.-Y., Weyer J., Willis S., Yu H., Zhou Z. 2012. Permanent genetic resources added to molecular ecology resources database 1 April 2012-31 May 2012. Molecular Ecology Resources 12 (5): 972-974. DOI: 10.1111/j.17550998.2012.03173.x

Anonymous 2014. Turks and Caicos Islands. The world fact book. Central Intelligence Agency, Langley VA, USA. Accessed March 2014 at: https://www.cia.gov/library/ publications/the-world-factbook/geos/tk.html

Ault J.S., Smith S.G., Bohnsack J.A. 2005. Evaluation of average length as an estimator of exploitation status for the Florida coral-reef fish community. ICES Journal of Marine Science 62 (3): 417-423. DOI: 10.1016/j.icesjms.2004.12.001

Box S.J., Canty S.W.J. 2010. The long and short term economic drivers of overexploitation in Honduran coral reef fisheries due to their dependence on export markets. Pp. 43-51. In: Proceedings of the 63rd Gulf and Caribbean Fisheries Institute. 1-5 November 2010, San Juan, Puerto Rico.

Cheung W.W.L., Sadovy de Mitcheson Y., Braynen M.T., Gittens L.G. 2013. Are the last remaining Nassau grouper Epinephelus striatus fisheries sustainable? Status quo in the Bahamas. Endangered Species Research 20: 27-39. DOI: 10.3354/esr00472

Cornish A., Eklund A.-M. 2003. Epinephelus striatus. In: IUCN 2013. IUCN Red List of Threatened Species. Version 2013.2. Accessed August 2013 at: www.iucnredlist.org

Ehrhardt N.M., Deleveaux V.K.W. 2007. The Bahamas' Nassau grouper (Epinephelus striatus) fishery-two assessment methods applied to a data-deficient coastal population. Fisheries Research 87 (1): 17-27. DOI: 10.1016/ j.fishres.2007.06.020

Froese R., Binohlan C. 2000. Empirical relationships to estimate asymptotic length, length at first maturity and length at maximum yield per recruit in fishes, with a simple method to evaluate length frequency data. Journal of Fish Biology 56 (4): 758-773. DOI: 10.1111/j.1095-8649.2000.tb00870.x

Graham R.T., Carcamo R., Rhodes K.L., Roberts C.M., Requena N. 2008. Historical and contemporary evidence of a mutton snapper (Lutjanus analis Cuvier, 1828) spawning aggregation fishery in decline. Coral Reefs 27 (2): 311-319. DOI: $10.1007 / \mathrm{s} 00338-007-0329-4$

Hardt M.J. 2009. Lessons from the past: the collapse of Jamaican coral reefs. Fish and Fisheries 10 (2): 143-158. DOI: $10.1111 /$ j.1467-2979.2008.00308.x

Jackson A.M., Semmens B.X., Sadovy de Mitcheson Y., Nemeth R.S., Heppell S.A., Bush P.G., Aguilar-Perera A., Claydon J.A.B., Calosso M.C., Sealey K.S., Schärer M.T., Bernardi G. 2014. Population structure and phylogeography in Nassau grouper (Epinephelus striatus), a mass-aggregating marine fish. PLoS ONE 9 (5): e97508. DOI: 10.1371/journal.pone.0097508.

Landsman S.J., Jadot C., Ashley M., Claydon J.A.B. 2009. Investigation of the Nassau grouper (Epinephelus striatus) fishery in the Turks and Caicos Islands: Implications for conservation and management. Pp. 82-89. In: Proceedings of the 61st Gulf and Caribbean Fisheries Institute. 10-14 November 2008, Gosier, Guadeloupe French West Indies.

Paddack M.J., Reynolds J.D., Aguilar C., Appeldoorn R.S., Beets J., Burkett E.W., Chittaro P.M., Clarke K., Esteves R., Fonseca A.C., Forrester G.E., Friedlander A.M., GarcíaSais J., González-Sansón G., Jordan L.K.B., McClellan D.B., Miller M.W., Molloy P.P., Mumby P.J., Nagelkerken I., Nemeth M., Navas-Camacho R., Pitt J., Polunin N.V.C., Reyes-Nivia M.C., Robertson D.R., Rodríguez-Ramírez A., Salas E., Smith S.R., Spieler R.E., Steele M.A., Williams I.D., Wormald C.L., Watkinson A.R., Côté I.M. 2009. Recent 
region-wide declines in Caribbean reef fish abundance. Current Biology 19 (7): 590-595. DOI: 10.1016/ j.cub.2009.02.041

Pauly D. 1984. Length-converted catch curves: A powerful tool for fisheries research in the tropics. Fishbyte 1 (2): 9-10.

Pauly D. 2008. Global fisheries: a brief review. Journal of Biological Research-Thessaloniki 9: 3-9.

Roberts C.M. 1997. Connectivity and management of Caribbean coral reefs. Science 278 (5342): 1454-1457. DOI: $10.1126 /$ science.278.5342.1454

Rudd M.A. 2003. Fisheries landings and trade of the Turks and Caicos Islands. Fisheries Centre Research Reports 11 (6): 149-161.

Sadovy Y., Eklund A.-M. 1999. Synopsis of biological data on the Nassau grouper, Epinephelus striatus (Bloch 1792), and the Jewfish, E. itajara (Lichtenstein, 1822). NOAA Technical Report NMFS 146 and FAO Fisheries Synopsis 157.

Sadovy de Mitcheson Y., Craig M.T., Bertoncini A.A., Carpenter K.E., Cheung W.W.L., Choat J.H., Cornish A.S., Fennessy S.T., Ferreira B.P., Heemstra P.C., Liu M., Myers R.F., Pollard D.A., Rhodes K.L., Rocha L.A., Russell B.C., Samoilys M.A., Sanciangco J. 2013. Fishing groupers towards extinction: a global assessment of threats and extinction risks in a billion dollar fishery. Fish and Fisheries 14 (2): 119-136. DOI: 10.1111/j.1467-2979. 2011.00455.x
Sheppard C., Rioja-Nieto R. 2005. Sea surface temperature 1871-2099 in 38 cells in the Caribbean region. Marine Environmental Research 60 (3): 389-396. DOI: 10.1016/ j.marenvres.2004.12.006

Thompson R., Munro J.L. 1978. Aspects of the biology and ecology of Caribbean reef fishes: Serranidae (hinds and groupers). Journal of Fish Biology 12 (2): 115-146. DOI: 10.1111/j.1095-8649.1978.tb04158.x

Vo A.-T.E., Dikou A., Newman S.P. 2008. Biological, socioeconomic, and political aspects of the Nassau grouper (Epinephelus striatus) fishery in the Turks and Caicos Islands. The Harvard Undergraduate Research Journal 1 (1): 80-87.

Woodley J., Alcolado P., Austin T., Barnes J., ClaroMadruga R., Ebanks-Petrie G., Estrada R., Geraldes F., Glasspool A., Homer F., Luckhurst B., Phillips E., Shim D., Smith R., Sealey K.S., Vega M., Ward J., Wiener J. 2000. Status of coral reefs in the northern Caribbean and western Atlantic. Pp. 261-285. In: Wilkinson C. (ed.) Status of coral reefs of the world: 2000. Australian Institute of Marine Science, Cape Ferguson, Queensland, and Dampier, Western Australia.

Received: 3 December 2013 Accepted: 4 May 2014 Published electronically: 30 June 2014 